\title{
Toll signal transduction pathway in bivalves: Complete cds of intermediate elements and related gene transcription levels in hemocytes of immune stimulated Mytilus galloprovincialis
}

\author{
Mylène Toubiana ${ }^{\mathrm{a}}$, Umberto Rosani ${ }^{\mathrm{b}}$, Sonia Giambelluca ${ }^{\mathrm{c}}$, Matteo Cammarata ${ }^{\mathrm{c}}$, Marco Gerdol $^{\mathrm{d}}$, \\ Alberto Pallavicini ${ }^{\mathrm{d}}$, Paola Venier ${ }^{\mathrm{b}, *}$, Philippe Roch ${ }^{\mathrm{a}, *}$ \\ ${ }^{a}$ Ecologie des Systèmes Marins Côtiers (EcoSym), CNRS-Université de Montpellier 2-IRD, cc 093, place E. Bataillon, 34095 Montpellier, France \\ ${ }^{\mathrm{b}}$ Department of Biology, University of Padua, Via U. Bassi, 58/B, 35121 Padua, Italy \\ ${ }^{\mathrm{c}}$ Department of Biological, Chemical and Pharmaceutical Science and Technology, University of Palermo, Via Archirafi 18, 90123 Palermo, Italy \\ ${ }^{\mathrm{d}}$ Laboratory of Genetics, University of Trieste, Via Licio Giorgieri 5, 34127 Trieste, Italy
}

\section{A R T I C L E I N F O}

\section{Article history:}

Received 13 January 2014

Revised 28 March 2014

Accepted 31 March 2014

Available online 4 April 2014

\section{Keywords:}

Signal transduction

Toll pathway

$\mathrm{NF}-\mathrm{KB}$

Innate immunity

Mollusks

Mytilus

\begin{abstract}
A B S T R A C T
Based on protein domain structure and organization deduced from mRNA contigs, 15 transcripts of the Toll signaling pathway have been identified in the bivalve, Mytilus galloprovincialis. Identical searches performed on publicly available Mytilus edulis ESTs revealed 11 transcripts, whereas searches performed in genomic and new transcriptome sequences of the Pacific oyster, Crassostrea gigas, identified 21 Toll-related transcripts. The remarkable molecular diversity of TRAF and IKK coding sequences of $C$. gigas, suggests that the sequence data inferred from Mytilus cDNAs may not be exhaustive. Most of the Toll pathway genes were constitutively and ubiquitously expressed in M. galloprovincialis, although at different levels, and clearly induced after in vivo injection with bacteria. Such over-transcription was more rapid and intense with Gram-negative than with Gram-positive bacteria. Injection of a fungus modulated the transcription of few Toll pathway genes, with the induction levels of TLR/MyD88 complex being always less intense. Purified LPS and $\beta$-glucans had marginal effect whereas peptidoglycans were ineffective. At the moment, we found no evidence of an IMD transcript in bivalves. In conclusion, mussels possess a complete Toll pathway which can be triggered either by Gram-positive or Gram-negative bacteria.
\end{abstract}

(c) 2014 Elsevier Ltd. All rights reserved.

\section{Introduction}

The cell signaling pathway triggered by Gram-positive bacteria and fungal infections, known as Toll pathway, has been described completely in insects (Valanne et al., 2011). Another cell signaling cascade, the IMD (immune deficiency) pathway regulates the insect response to Gram-negative bacterial infections (Lemaitre and Hoffmann, 2007). Though the Toll and IMD pathways are mediated by different intermediate molecules they end with the translocation of similar Rel/NF- $\kappa$ B proteins inside the nucleus and induce the transcription of AMPs (antimicrobial peptides) and other genes.

Abbreviations: aa, amino acids; AMP, antimicrobial peptide; BG, beta-glucans; cds, coding sequence; EF1- $\alpha$, elongation factor 1-alpha; EST, expressed sequence tags; IMD, immune deficiency; LPS, lipopolysaccharides; NF- $\kappa B$, nuclear factorkappa B; nt, nucleotide; ORF, open reading frame; PAMPs, pathogen associated molecular patterns; PGN, peptidoglycans; p.i., post-injection; SSW, sterile seawater.

* Corresponding authors. Tel.: +33 467144712 (P. Roch).

E-mail addresses: paola.venier@unipd.it(P.Venier),philippe.roch@univ-montp2. fr (P. Roch).
The Toll pathway of Drosophila is comparable to the mammalian signaling cascades downstream of the interleukin-1 (IL-1) and TLR (Toll-like) receptors. By contrast, the IMD pathway is similar to the tumor-necrosis-factor (TNF) receptor pathway of mammals (Ferrandon et al., 2007; Hoffmann, 2003). After AMPs were discovered in bivalves (reviewed by (Li et al., 2011), regulation of their transcription levels in response to experimental immune stimulation was reported in the Mediterranean mussel, Mytilus galloprovincialis (Mitta et al., 1999a,b, 2000b; Sonthi et al., 2012; Venier et al., 2011), the deep-sea hydrothermal vent mussel, Bathymodiolus azoricus (Bettencourt et al., 2007), the Pacific oyster, Crassostrea gigas (Gonzalez et al., 2007; Gueguen et al., 2006; Schmitt et al., 2012), the carpet-shell clam, Ruditapes decussatus (Gestal et al., 2007), the hard clam, Mercenaria mercenaria (Perrigault et al., 2009), the triangle-shell pearl mussel, Hyriopsis cumingii (Ren et al., 2011) and the blue mussel, Mytilus edulis (Tanguy et al., 2013).

Concomitant homology searches based on insect or mammal sequences were performed to find transcripts of the Toll pathway in bivalves. We previously reported the presence of IKK (inhibitor 
of kappa-B kinase) in C. gigas and demonstrated its functional properties by transferring deleted cDNA into human cell line (Escoubas et al., 1999). Subsequent EST analysis in oyster revealed transcripts for the adaptor MyD88 (myeloid differentiation factor 88), TRAF (TNF receptor-associated factor), ECSIT (evolutionarily conserved signaling intermediate in Toll pathways) and IkB (inhibitor of nuclear factor kappa-B) (Gueguen et al., 2003). One year later, the first Rel/NF- $\kappa B$ homologues were characterized also in oyster (Montagnani et al., 2004) and in the deep-sea hydrothermal vent mussel, B. azoricus (Bettencourt et al., 2007). Sequences denoting the oyster Rel/NF- $\kappa B$ pathway were still incomplete. Nevertheless, the presence of $\mathrm{I} \kappa \mathrm{B}$ (Cunningham et al., 2006; Montagnani et al., 2008), NF- $\kappa B$ (Cunningham et al., 2006), Rel (Wu et al., 2007) and IKK (Xiong et al., 2008) have been confirmed in oysters. More recently, we reported the presence of 23 TLR in M. galloprovincialis, along with 3 MyD88. Induction of their transcription following challenges with bacteria and a fungus suggested the involvement of some of these transcripts in the mussel immune response (Toubiana et al., 2013).

Here, we present the cds sequences of 15,11 and 21 transcripts which outline the Toll pathway in M. galloprovincialis, M. edulis and C. gigas, respectively. To investigate their functional role, we quantified the related gene transcription levels in hemocytes from $M$. galloprovincialis injected with Gram-negative bacteria (Vibrio splendidus LGP32, Vibrio anguillarum), Gram-positive bacteria (Microccocus luteus), a fungus (Fusarium oxysporum) and purified PAMPs (pathogen associated molecular patterns) such as LPS (lipopolysaccharides), PGN (peptidoglycans) and BG ( $\beta$-glucans).

\section{Materials and methods}

\subsection{Bioinformatic analysis}

We used the same sets of ESTs and Illumina reads from M. galloprovincialis as previously reported for MgTLR and MgMyD88 (Toubiana et al., 2013). Contigs assembled by CLC Genomics Workbench 5.1 and corresponding to the six possible ORF were scanned with HMMer 3 (Eddy, 2011). Protein signatures were retrieved using SMART (http://smart.embl.de) and SOSUI (http://bp.nuap.nagoya-u.ac.jp/sosui), and completed by manual alignments on the elements composing the insect and mammal Toll-TLR/NF- $\kappa B$ signaling pathway. Only transcripts encoding proteins with canonical domain organization have been considered. PolyA was reported only for MgIKB-1 since the program assembly automatically removed repetitive nucleotides.

Taking advantage of the massive release of $M$. edulis ESTs (Philipp et al., 2012), we looked for Toll pathway intermediate transcripts using SMART, protein BLAST (http://blast.ncbi.nlm.nih.gov) and Multalin (http://multalin.toulouse.inra.fr) softwares. Data from the genome of the Pacific oyster, $C$. gigas, released by (Zhang et al., 2012) have been reinforced by new Illumina reads we generated from $C$. gigas gills. Contig assembly and searches based on protein signature in oyster were as described for mussels.

To perform phylogenetic analyses, relevant sequences from selected organisms with a fully sequenced genome have been collected, aligned using MUSCLE (www.drive5.com/muscle) and informative positions have been retrieved with GBlocks (Talavera and Castresana, 2007). Trees were using a neighborhood joining clustering method with 1000 bootstrap replicates using MEGA 6 (www.megasoftware.net).

\subsection{In vivo treatment of mussels and tissue sampling}

Adult Mediterranean mussels, M. galloprovincialis (PalavasPrévost lagoon, France), challenged by injecting into the posterior adductor muscle $100 \mu \mathrm{l}$ of SSW (sterile seawater) with $10^{7}$ of the Gram-negative bacteria, V. splendidus LGP32 (Gay et al., 2004), V. anguillarum (Institut Pasteur-France ATCC 19264), or of the Gram-positive bacterium, M. luteus (Institut Pasteur-France ATCC 4698), were from (Li et al., 2010). M. galloprovincialis challenged with $2 \times 10^{4}$ spores of filamentous fungus, $F$. oxysporum, were from (Sonthi et al., 2012). Challenges with soluble PAMPs consisted in one injection into the posterior adductor muscle of $50 \mu$ of SSW containing $10 \mu \mathrm{g}$ of LPS from Escherichia coli serotype 026:B6 (Sigma), $10 \mu \mathrm{g}$ of PGN from M. luteus (Sigma), or $10 \mu \mathrm{g}$ of BG from Saccharomyces cerevisiae (Sigma). Controls were both unchallenged mussels and mussels injected with SSW.

Hemolymph was collected at 0 (unchallenged), 3, 6, 9 and $24 \mathrm{~h}$ p.i. into anti-coagulant modified Alsever's solution from the posterior adductor muscle (10 mussels/end point). Complete sets of challenges and related samplings have been performed 4 times. Pooled hemocytes have been pelleted by centrifugation and total RNA extracted by Trizol Reagent (Invitrogen). To evaluate the constitutive tissue-specific transcription, total RNA was extracted by Trizol Reagent (Invitrogen) from hemocytes and from dissected foot, digestive gland, muscle, gills and mantle (one pool of 3 unchallenged mussels). RNA was then purified by precipitation with sodium acetate $0.3 \mathrm{M}$, UV-measured (ND-1000, NanoDrop Technologies) and quality-checked by capillary electrophoresis (RNA 6000 Nano LabChip, Agilent Technologies). First strand cDNA has been synthesized from $1 \mu \mathrm{g}$ of total RNA using $0.5 \mu \mathrm{g}$ of hexaprimers (Promega), $2 \mathrm{mM}$ dNTPs (Promega) and $200 \mathrm{U}$ of murine leukemia virus reverse transcriptase (M-MLV RT, Promega) in $25 \mu \mathrm{l}$ final volume. Reverse transcriptase products were diluted 1/20 and kept at $-20^{\circ} \mathrm{C}$ until use.

\subsection{Quantification of gene transcription levels}

Primers to be used in end-point PCR and qPCR have been designed from cDNAs using the LightCycler Probe Design 2.0 software V.1.0.R.36 (Roche) and optimized by hand regarding specificity and efficacy (Table 1). Primers for MgTLR, MgMyD88 and MgEF1- $\alpha$ were from (Toubiana et al., 2013). All the resulting amplicons have been sequenced (LGC Genomics, Berlin-Germany) to control the expected identity.

Constitutive transcription levels of 15 Toll pathway elements were evaluated by end-point PCR after 35 cycles. PCR mix contained $1 \mu \mathrm{l}$ of template, $0.4 \mu \mathrm{M}$ of each specific primer, $0.8 \mathrm{mM}$ of dNTPs and $0.625 \mathrm{U}$ of GoTaq polymerase (Promega) in $25 \mu \mathrm{l}$ final volume. PCR started with initial denaturation at $95^{\circ} \mathrm{C}$ for $2 \mathrm{~min}$, followed by 35 cycles including $30 \mathrm{~s}$ at $95^{\circ} \mathrm{C}, 30 \mathrm{~s}$ annealing at $58{ }^{\circ} \mathrm{C}$ (MgRIP-like), $62{ }^{\circ} \mathrm{C}$ (MgEF1- $\alpha$, MgTLR-r, MgTOLLIP) or $60^{\circ} \mathrm{C}$ (all other genes), $30 \mathrm{~s}$ elongation at $72^{\circ} \mathrm{C}$, and $5 \mathrm{~min}$ final elongation at $72{ }^{\circ} \mathrm{C}$. Results have been visualized by electrophoresis in $2 \%$ agarose gel.

qPCR was performed on a LightCycler 480 (Roche) in 384-well plates taking advantage of a JANUS automated workstation (Perkin Elmer) to distribute the reaction volumes. The PCR mix contained $2 \mu \mathrm{l}$ of template, $0.4 \mu \mathrm{M}$ (MgTLR-n, MgMyD88-b, MgTOLLIP), $0.8 \mu \mathrm{M}$ (MgEF1- $\alpha$, MgTLR-a, MgIRAK-a/b, MgIKK-2, MgIKK $\gamma /$ NEMO, MgRel) or $0.6 \mu \mathrm{M}$ (all other genes) of each specific primer, $3 \mu \mathrm{l}$ of Lightcycler 480 SYBR Green I Master (Roche), adjusted to $6 \mu$ with nuclease-free water. After initial heating at $95^{\circ} \mathrm{C}$ for $10 \mathrm{~min}, 45$ cycles including $10 \mathrm{~s}$ at $95^{\circ} \mathrm{C}, 10 \mathrm{~s}$ annealing at 58,60 or $62{ }^{\circ} \mathrm{C}$ (see above) were performed before a final step of $10 \mathrm{~s}$ at $72{ }^{\circ} \mathrm{C}$. Melting temperatures were measured by returning to $65^{\circ} \mathrm{C}$ in $30 \mathrm{~s}$ and gradual heating to $95^{\circ} \mathrm{C}$. Complete sets of the 4 biological replicates have been measured twice. Negative control wells containing water in place of the cDNA template have been included in each run to ensure absence of contamination. Standard curves were obtained using 10-fold serial dilutions of corresponding 
Table 1

Primers used in this study with corresponding size of amplicons. Primers for the five MgTLR, the three MgMyD88 and MgEF1- $\alpha$ were from (Toubiana et al., 2013).

\begin{tabular}{|c|c|c|c|}
\hline Targeted gene & Forward $\left(5^{\prime}-3^{\prime}\right)$ & Reverse $\left(5^{\prime}-3^{\prime}\right)$ & Amplicon size (bp) \\
\hline MgTLR-a & ATTTCAGAAGGCTTTTCACCA & CAGAACAGTTTGTCGGAGTATT & 150 \\
\hline MgTLR-b & GGAGTTTCAGATAGCTCATCA & GACCAGGACCATACAGTCTT & 101 \\
\hline MgTLR-i & AGGATGGCTTGAACTGGATT & AGTCGAGTAGGCTTTCTGTA & 110 \\
\hline MgTLR-n & GGAGAGACGCAGACGTTATG & CTCGCCGACACCAGTTTGAT & 139 \\
\hline MgTLR-r & TTGAATAACAACGCTCTGGTC & CTTTGCAGTCCGAGAAATACTT & 178 \\
\hline MgMyD88-a & GCAGAAATGATTGCTAACAGATG & CTGGTGATAAGGACTGTGCT & 112 \\
\hline MgMyD88-b & CTGGAGACATTGATGGCAGT & CTCTACCTGGCACACATAGT & 147 \\
\hline MgMyD88-c & ATGAAACCAGATACCTGACAAT & TACAAAGTAACCGTCCTTGC & 113 \\
\hline MgTOLLIP & TGATACCACCTCTGCGACTC & ААСТСТTTCATCTGCCATTACT & 115 \\
\hline MgIRAK-a & GTAGAGGAAAACGCAGAAGTTA & TTCACATTCAAGAGATGATTCAGT & 120 \\
\hline MgIRAK-b & TTTGAGGAAGATGCTAAACCTG & CAACTGAGAAACCCAAGAAAG & 127 \\
\hline MgECSIT & GCCAGCCAAGACATTCAGAG & ACTGTATTGCCTGTGGAGTT & 127 \\
\hline MgTRAF-3 & ATCСТTACAAАСТССТCTTGG & CACAACCCTCACACATACG & 131 \\
\hline MgTRAF-6 & GAAGGCTGTAAAGTGATAGAAGTT & CTGAGATAGATGATGAGGTAAGTC & 135 \\
\hline MgRIP-like & CATACAGAGTGCTCAGAACAT & TTGTCTACTTTGGCTGGCTTA & 123 \\
\hline MgTAK-1 & TAGGAGGACCTGCTTTCAGAAT & CCTTGCCACTTCAATCATAG & 152 \\
\hline MgIKK-1 & AGCCACTAACTCAGAACTACA & GGACTATTCCAACATTGCGT & 180 \\
\hline MgIKK-2 & AGGAGCATTCTCTTGTGTATTT & CATCTGTTTCCCGTTGAGTT & 113 \\
\hline MgIKK $\gamma /$ NEMO & AGGCATTTCATAGTCTGAGT & AGGCATTTCATAGTCTGAGT & 174 \\
\hline MgIкB-1 & GCAATCGGCAAATCACTTCA & TTCTGGCGTTACTCTGTCG & 186 \\
\hline МgIкB-2 & GGAAGTCGATTGTGCTATGAT & CAGTCTCGTTGATTTGTGCTA & 197 \\
\hline MgRel/p65 & GGTCACTGGGACTGTTAGATA & GCTCCAAGGTTACTGAACG & 142 \\
\hline MgNF-кB p100/105 & AACTCCAAATCGTCGTCCTA & GCTGAAACGGTATGTGTTGA & 233 \\
\hline MgEF1- $\alpha$ & CAAGACCCACAGACAAAGC & GGAGCAAAGGTAACAACCAT & 130 \\
\hline
\end{tabular}

amplicon in a solution containing $10 \mu \mathrm{g} / \mathrm{ml}$ sonicated salmon sperm DNA (Sigma). Data were analysed with LightCycler 480 software v.1.5.0.39 (2nd derivative max algorithm) and crossing threshold values $(\mathrm{Ct})$ were converted into initial mRNA quantities by using standard curves. We measured the transcription of elongation factor 1-alpha (EF1- $\alpha$ ) in each sample and we found it stable whatever the challenge and sampling time. Hence, we confirmed it as reference gene. Transcription levels of the genes of interest were normalized to the EF1- $\alpha$ transcription level and reported as $x$-fold the unchallenged controls, the latter adjusted to 1 . Results are presented as arithmetic mean \pm SD of the 4 biological samples measured in duplicate. To compare the resulting gene expression levels, we used the Mann-Whitney test (Instat 3.01 software, GraphPad, San Diego-CA) related to low number of samples, with $p$ values $<0.05$ revealing significant differences.

\section{Results}

3.1. The $15 \mathrm{cds}$ and related protein signature domains identified in $M$. galloprovincialis

Table 2 reports the identity, variant label, expected length and structural domains of the Toll pathway proteins inferred from comprehensive mussels and oyster transcriptomes (detailed in Section 2). Related sequence accession numbers of $M$. galloprovincialis and $C$. gigas are in Table 3. Fig. 1 shows the phylogenic trees of 11 transcript groups involved in the Toll signaling, and illustrates their domain composition in parallel. $M$. edulis aa sequences deduced from our new assemblies performed on $M$. edulis ESTs (Philipp et al., 2012) are in the Supplementary Table 1. Sequence accession numbers of non-bivalve species can be found in the Supplementary Table 2 .

TOLLIP (Toll interacting protein) is an ubiquitin-binding protein that interacts with several TLR signalling cascade elements. It is involved in the turnover of IL1R (interleukin 1-receptor)-associated kinase and facilitates endosomal protein sorting for lysosomal degradation (Capelluto, 2012). We identified MgTOLLIP as a contig of $1785 \mathrm{nt}$, including a cds of $861 \mathrm{nt}$ (286 aa, estimated MM $32,209 \mathrm{Da}$ ) with the central C2 domain (aa 65-174) recruited in targeting the endosomal membrane and the C-terminal CUE (coupling of ubiquitin conjugation to endoplasmic reticulum degradation) domain (aa 241-283) expected to bind ubiquitin-conjugating enzymes. Even though the phylogenetic analysis did not perfectly resolve the nodes within branches, a well-supported cluster includes all TOLLIP from bivalves and deuterostomes. TOLLIP proteins from arthropods are either missing or quite divergent: Apis mellifera and Nasonia vitripennis retained the expected domain organization, whereas CUE domain was lacking from Bombyx mori protein structure and no TOLLIP has been released from Drosophila melanogaster and C. quinquefasciatus.

Two contigs belonging to the IRAK (interleukin-1 receptor-associated kinase) family have been identified. The $M g I R A K-a$ contig has $3070 \mathrm{nt}$ and includes a cds of $2943 \mathrm{nt}$ (980 aa, estimated MM $111,640 \mathrm{Da}$ ). It contains the canonical fold of protein kinases consisting mainly of a N-terminal DD (death domain, aa 15-108) and the C-terminal S_TKc (serine/threonine protein kinase catalytic) domain (aa 250-526). The MgIRAK-b contig has 1756 nt and comprises a cds of $1602 \mathrm{nt}$ (533 aa, estimated MM 60,348 Da) with the DD (aa 13-114) and S_TKc domains (aa 250-526). According to the phylogenetic analysis, MgIRAK-a is closely similar to C. gigas IRAK-1 and can be related to Pelle of arthropods with good clustering and high bootstrap value. On the opposite, MgIRAK-b is almost identical to both $M$. edulis IRAK-b and $C$. gigas IRAK-4 and can be related to deuterostomes, although bootstrap values were not very high. Worth noticing, human IRAK-1, -2 and -3 are clearly apart.

MgECSIT (evolutionarily conserved signaling intermediate in Toll pathways) is a contig of $1510 \mathrm{nt}$ containing a cds of $1347 \mathrm{nt}$ (448 aa, estimated MM 51,942 Da) with the typical ECSIT structural domain (aa 78-303). Domain organization is well conserved in all analyzed sequences which segregated in three separated clusters with mussels and oyster clearly grouped together. ECSIT is known to be a single-copy gene whose functional constraints may have prevented its evolutionary diversification.

MgTRAF-3 (TNF receptor-associated factor 3) contig of $1943 \mathrm{nt}$ with a 5'UTR of $165 \mathrm{nt}$, a cds of $1710 \mathrm{nt}$ (569 aa, estimated MM $64,797 \mathrm{Da}$ ), and a $3^{\prime} \mathrm{UTR}$ of $68 \mathrm{nt}$. It displays the canonical organization of three functional domains: the N-terminal ZF (zinc-finger)-ring domain which functions as an E3 ubiquitin ligase (aa 36-78), two ZF-Traf domains (aa 126-180, 180-239) and the C-terminal MATH (meprin-associated TRAF homology) domain (aa 420-543). A second TRAF contig, related to factor 6 , and named 


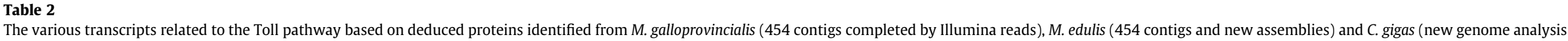
reinforced by Illumina reads).

\begin{tabular}{|c|c|c|c|c|c|c|c|c|c|}
\hline \multirow[t]{2}{*}{ Gene product ID } & \multicolumn{3}{|c|}{ Mytilus galloprovincialis } & \multicolumn{3}{|l|}{ Mytilus edulis } & \multicolumn{3}{|l|}{ Crassostrea gigas } \\
\hline & Variant number & Protein length & Structural domains & Variant number & Protein length & Structural domains & Variant number & Protein length & Structural domains \\
\hline TOLLIP & & 286 & C2, CUE & & 282 & C2, CUE & & 284 & C2, CUE \\
\hline IRAK & $\begin{array}{l}\mathrm{a} \\
\mathrm{b}\end{array}$ & $\begin{array}{l}980 \\
533\end{array}$ & $\begin{array}{l}\text { DD, S_TKc } \\
\text { DD, S_TKc }\end{array}$ & $\mathrm{b}$ & 533 & DD, S_TKc & $\begin{array}{l}1 \\
4\end{array}$ & $\begin{array}{l}1047 \\
536\end{array}$ & $\begin{array}{l}\text { DD, S_TKc } \\
\text { DD, S_TKc }\end{array}$ \\
\hline ECSIT & & 448 & ECSIT & & 435 & ECSIT & & 451 & ECSIT \\
\hline TRAF & $\begin{array}{l}3 \\
6\end{array}$ & $\begin{array}{l}569 \\
596\end{array}$ & $\begin{array}{l}\text { ZF-ring, 2x ZF-traf, MATH } \\
\text { ZF-ring, 2x ZF-traf, MATH }\end{array}$ & 6 & 596 & ZF-ring, 2x ZF-traf, MATH & $\begin{array}{l}2 \\
3 \mathrm{a} \\
3 \mathrm{~b} \\
3 \mathrm{c} \\
3 \mathrm{~d}\end{array}$ & $\begin{array}{l}520 \\
553 \\
498 \\
603 \\
581\end{array}$ & $\begin{array}{l}\text { ZF-ring, 2x ZF-traf, MATH } \\
\text { ZF-ring, ZF-traf, MATH } \\
\text { ZF-ring, MATH } \\
\text { ZF-ring, 2x ZF-traf, MATH } \\
\text { ZF-ring, 2x ZF-traf, MATH }\end{array}$ \\
\hline RIP-like & & 227 & DD & & 126 & DD & & 238 & RHIM, DD \\
\hline TAK & 1 & 674 & S_TKc & & - & - & 1 & 677 & S_TKc \\
\hline IKK & $\begin{array}{l}1 \\
2\end{array}$ & $\begin{array}{l}598^{*} \\
714\end{array}$ & $\begin{array}{l}\text { S_TKc } \\
\text { S_TKc }\end{array}$ & & $396^{*} /^{* *}$ & S_TKc & $\begin{array}{l}\text { Alpha } \\
\text { Epsilon1 } \\
\text { Epsilon2 }\end{array}$ & $\begin{array}{l}730 \\
732 \\
620 \\
720\end{array}$ & $\begin{array}{l}\text { S_TKc } \\
\text { S_TKc } \\
\text { S_TKc } \\
\text { S_TKc }\end{array}$ \\
\hline IKK $\gamma /$ NEMO & & 705 & NEMO, ZF_C2H2 & & 705 & NEMO, ZF_C2H2 & & 686 & NEMO, ZF_C2H2 \\
\hline ІкB & $\begin{array}{l}1 \\
2\end{array}$ & $\begin{array}{l}392 \\
355\end{array}$ & $\begin{array}{l}\text { 6x Ank } \\
5 x \text { Ank }\end{array}$ & $\begin{array}{l}1 \\
2\end{array}$ & $\begin{array}{l}392 \\
355\end{array}$ & $\begin{array}{l}\text { 6x Ank } \\
5 x \text { Ank }\end{array}$ & $\begin{array}{l}\text { Cactus } \\
\text { Alpha } \\
\text { Epsilon }\end{array}$ & $\begin{array}{l}383 \\
337 \\
343\end{array}$ & $\begin{array}{l}\text { 6x Ank } \\
4 x \text { Ank } \\
6 x \text { Ank }\end{array}$ \\
\hline Rel/p65 & & 597 & RHD, IPT & & 597 & RHD, IPT & & 615 & RHD, IPT \\
\hline $\begin{array}{l}\text { NF- } \kappa B \\
\text { p100/105 }\end{array}$ & & 1187 & RHD, IPT, 6x Ank, DD & & 1185 & RHD, IPT, 6x Ank, DD & & 1490 & RHD, IPT, 11x Ank, DD \\
\hline
\end{tabular}

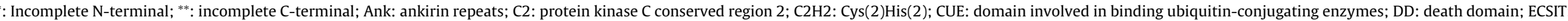

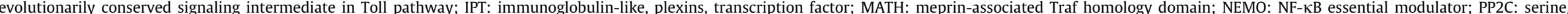

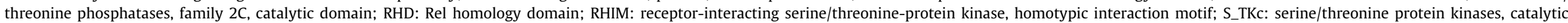
domain; TIR: Toll/IL-1R homologous region; Uricase: urate oxidase; ZF-ring: zinc-finger ring. 
Table 3

Accession numbers of $M$. galloprovincialis and $C$. gigas sequences used in the present study. M. edulis aa sequences are in Supplementary Table 1.

\begin{tabular}{|c|c|c|}
\hline Transcripts & Mytilus galloprovincialis & Crassostrea gigas \\
\hline TOLLIP & КС994890 & ЕКС 34473 \\
\hline IRAK & $\begin{array}{l}\text { a KF110683 } \\
\text { b KC994891 }\end{array}$ & $\begin{array}{l}1 \text { ЕКС } 30853 \\
4 \text { ЕКС } 43058\end{array}$ \\
\hline ECSIT & KC994892 & HQ225834 \\
\hline TRAF & $\begin{array}{l}3 \text { KJ513264 } \\
6 \text { КС994893 }\end{array}$ & $\begin{array}{l}2 \text { ЕКС22057 } \\
\text { 3a ЕКС31562 } \\
\text { 3b ЕКС42495 } \\
\text { 3c ЕКC18970 } \\
\text { 3d ЕКС37852 }\end{array}$ \\
\hline RIP-like & КС994894 & - \\
\hline TAK & $1 \mathrm{KJ} 513265$ & 1 ЕКС20089 \\
\hline IKK & $\begin{array}{l}1 \text { KF015301 } \\
2 \text { KF015302 }\end{array}$ & $\begin{array}{l}\text { АAC05683 } \\
\alpha \text { EKC26811 } \\
\varepsilon 1 \text { EKC41454 } \\
\varepsilon 2 \text { EKC36402 }\end{array}$ \\
\hline IKK $\gamma /$ NEMO & KJ513263 & EKC28073 \\
\hline $\mathrm{I} \kappa \mathrm{B}$ & $\begin{array}{l}1 \text { KF015299 } \\
2 \text { KF015300 }\end{array}$ & $\begin{array}{l}\text { Cactus ЕКС } 37718 \\
\alpha \text { ЕКС } 30840 \\
\varepsilon \text { ЕКС } 37831\end{array}$ \\
\hline Rel/p65 & HQ673623 & AYO39648 \\
\hline$N F-\kappa B$ & KF051275 & ЕКС31121 \\
\hline
\end{tabular}

MgTRAF-6, spans for $4143 \mathrm{nt}$, starting with a large 5'UTR of $990 \mathrm{nt}$

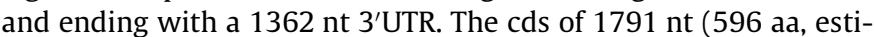
mated MM 67,827 Da) contains also typical structures: the ZF-ring (aa 47-85), two ZF domains (aa 131-185; 185-243) and the MATH domain (aa 448-586). For easier visualization, only the $H$. sapiens, $D$. melanogaster, $C$. gigas and mussel sequences are displayed in the phylogenetic tree. The clustering confirmed that mussel TRAFs refer to factors 3 and 6, with MgTRAF-6 and MeTRAF-6 being almost identical. Among the numerous sequences reported from the $C$. gigas genome, only five contained the canonical TRAF structure, and other seven showed partial domain association or even only the trivial MATH domain. Hence, they were not included in the phylogenetic analysis. The so-called CgTRAF-3d resembles Mytilus TRAF-6 whereas CgTRAF-2 and $-3 a,-3 b,-3 c$ are similar to the $H$. sapiens TRAF-2 and -3 .

MgRIP (receptor-interacting protein) contig is $1280 \mathrm{nt}$ long and contains a cds of $684 \mathrm{nt}$ (227 aa, estimated MM 25,716 Da) with a unique DD at the C-terminal end (aa 132-225). RIP are a group of threonine/serine protein kinases with a relatively conserved kinase domain and distinct non-kinase regions. Different structural domains, such as DD, caspase activation and recruitment domain (CARD), can be found in different RIP family members. Looking at the domain architecture, MeRIP sequence is probably incomplete. The sequences from bivalves have little in common with RIP from deuterostomes since they miss the N-terminal large S_TKc domain, fundamental for their kinase activity. Bivalve sequences have been identified by BLAST due to their DD similarity, but their clustering is not well supported due to low bootstrap values, even with IMD from arthropods, an homologue of vertebrate RIP, which also do not contain the kinase domain. Only RIP1 and RIP2 out of the 7 members of the human RIP protein family have a C-terminal DD (Zhang et al., 2010), but all of them contained one kinase domain. Consequently, we suggested to named the Mytilus sequences, MgRIP-like and MeRIP-like.

TAK-1 (transforming growth factor activated kinase-1, or MAP3K7) is an ubiquitin-dependent kinase of IKK (inhibitor of kappa-B kinase). MgTAK-1 is a contig of 3022 nt long including a cds of $2025 \mathrm{nt}$ coding for a protein of 674 aa (estimated MM
$74,758 \mathrm{Da}$ ) which includes the large S_TKc domain (aa 14-264). TAK-1 can be activated by various extracellular signals, also proinflammatory cytokines and TLRs. In response to TNF and IL-1, complex interactions of TAK-1, and ASK-1 (apoptosis signal-regulating kinase 1) with specific binding proteins regulate both NF$\kappa \mathrm{B}$ and MAPK signaling pathways, and eventually the transcription of genes for divergent biological activities (Kim et al., 2014). TAK-1 is known to be a single-copy gene and the sequences from molluscs are much closer to those from deuterostomes than they are to those from arthropods which clustered together with high support (Fig. 1).

Two IKK (inhibitor of kappa-B kinase) contigs have been isolated: $M g I K K-1$ of $1951 \mathrm{nt}$ including a cds of $1794 \mathrm{nt}$ (598 aa) with incomplete N-terminal, and MgIKK-2 of $2844 \mathrm{nt}$ with a cds of $2145 \mathrm{nt}$ (714 aa, estimated MM 81,452 Da). The typical S_TKc domain, similar to the one of IRAK and TAK, has been located at the $\mathrm{NH}_{2}$-terminal end (aa 1-160 and 12-208, respectively). The phylogenetic analysis clearly show a distinction between two major sub-groups of IKK based on $H$. sapiens terminology: the first including the IKK complex sub-units, $\alpha$ and $\beta$, the second including IKK-related kinases, such are IKK-epsilon and TANK-binding kinase 1 (TBK1). MgIKK-1 belongs to the IKK- $\alpha / \beta$ sub-group and $M g I K K-2$ to the IKK-epsilon/TBK1 sub-group. The M. edulis sequence has not been included in the tree because it is largely incomplete.

$M g I K K \gamma /$ NEMO (NF- $\mathrm{KB}$ essential modulator) contig of $3665 \mathrm{nt}$ coded for a protein of 705 aa (estimated MM 81,625 Da) and included the typical NEMO domain (aa 66-133) and the ZFC2H2 (zinc-finger-Cys(2)His(2)) domain (aa 680-700). Almost identical is the virtual protein identified in $M$. edulis with 4 aa differences out of 705, possibly resulting from sequencing errors. IKK $\gamma /$ NEMO is a regulatory sub-unit, part of the trimeric protein complex with IKK- $\alpha$ and $-\beta$, which activates or inhibits the protein kinase activities (Shifera, 2010). In vertebrates, optineurins share considerable homology with IKK $\gamma / \mathrm{NEMO}$, making difficult their phylogenetic identification. However, optineurin is not found in the IKK- $\alpha / \beta$ complex, and despite a controversial role in cell signaling reported in the literature, it seems that optineurin cannot substitute IKK $\gamma /$ NEMO in NF- $\kappa B$ activation (Munitic et al., 2013) Only the protein dmIKK $\gamma /$ Kenny possessing the structural characteristics common to NEMO and optineurin, and involved in signaling pathways leading to the activation of NF- $\kappa \mathrm{B}$, has been reported from $D$. melanogaster. That is the reason why we clearly identified the sequences found in molluscs as IKK $\gamma /$ NEMO. They are more closely related to deuterostomes proteins than to those from arthropods. In fact, IKK $\gamma /$ NEMO sequences are quite divergent across species as the typical NEMO Pfam domain of S. purpuratus, S. kowalevskii and D. melanogaster is even not recognized by SMART.

Two I $\kappa$ B (inhibitor of nuclear factor kappa-B) contigs have been isolated: MgIKB-1 of 1669 nt with a cds of $1179 \mathrm{nt}$ (392 aa, estimated MM 43,432 Da), and MgIKB-2 of 1532 nt with a cds of 1068 nt (355 aa, estimated MM 39,774 Da), characterized by six and five ankyrin repeats, respectively. For an easier interpretation, only the human and insect sequences were included in the phylogenic tree, in addition to bivalves. The mussel and oyster sequences segregated in an exclusive cluster, clearly separated from the 4 human NF- $\kappa$ B inhibitors (Fig. 1).

The partial Rel-related sequence of $342 \mathrm{nt}$ that we previously released has been extended to $2604 \mathrm{nt}$, namely the $\mathrm{MgRel}$ contig. Between 189 nt of the $5^{\prime}$ UTR and 620 nt of the 3'UTR, the complete cds of $1794 \mathrm{nt}$ (597 aa, estimated MM 66,485 Da) displays in sequence the RHD (Rel homology domain)-n Dorsal Dif-like domain (aa 94-261) and the IPT (Ig-like, plexins, transcription factors)-NF- $\kappa \mathrm{B}$ domain (aa 266-369) ankyrin protein binding sites and dimerization interface. Both domains contain several DNA binding sites. RHD and IPT domains are common to both Rel and 


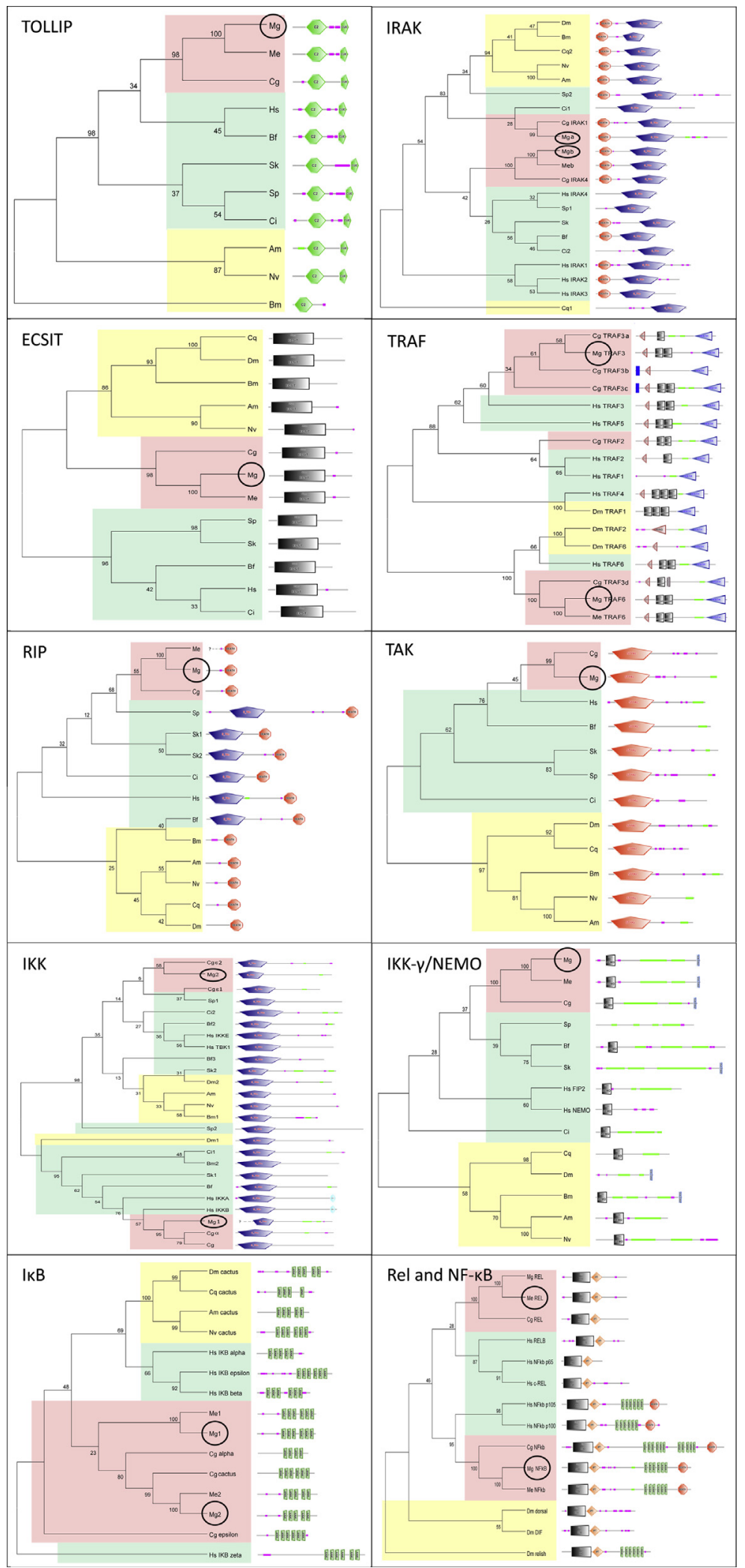

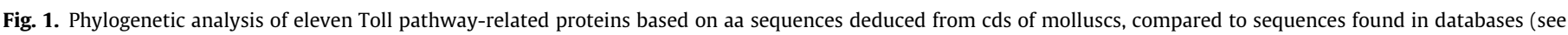

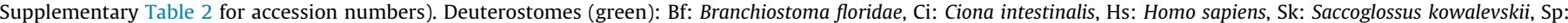

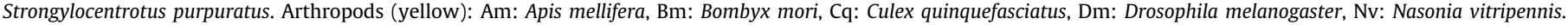

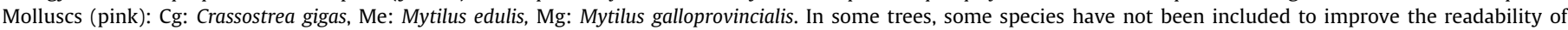

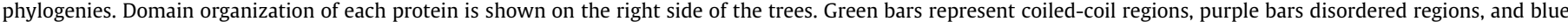

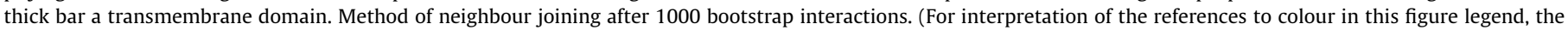
reader is referred to the web version of this article.) 
$\mathrm{NF}-\kappa \mathrm{B}$ and they have been considered together in order to discriminate the two type of transcripts (see below).

$M g N F-\kappa B$ (nuclear factor kappa-B)-like contig consisted of $4258 \mathrm{nt}$ and contains a cds of $3564 \mathrm{nt}$ (1187 aa, estimated MM $132,594 \mathrm{Da})$. It is a complex protein featured by nine domains: one RHD (aa 53-241), one IPT domain (aa 248-350) with ankyrin protein binding sites and dimerization interphase, six ankyrin domains (aa 755-968) and one DD (aa 1066-1153). Similarly to Rel, the RHD and IPT domains of MgNF- $\kappa$ B contained several DNA binding sites.

RHD and IPT domains common to both Rel and NF- $\kappa$ B have been considered within the same phylogenetic tree, along with reference human and $D$. melanogaster sequences. In addition to the domain organization, the tree revealed that bivalves do possess one Rel-B/c-Rel/p65 and one NF- $\kappa \mathrm{B} / \mathrm{p} 100 / 105$ orthologous genes. $M$. galloprovincialis and $M$. edulis sequences are almost identical and closely related to the $C$. gigas ones (Fig. 1).

Despite the successful identification of many Toll/NF- $\kappa B$ intermediate elements, our screening of the $M$. galloprovincialis transcriptome did not reveal IMD, the insect homologue of vertebrate RIP, involved in the response to bacterial PAMPs (Lemaitre and Hoffmann, 2007).

\subsection{Toll pathway transcripts in M. edulis and C. gigas}

Mining the available $M$. edulis EST database (Philipp et al., 2012), we identified 11 cDNAs related to Toll pathway, only one of them with incomplete C-terminal end. Revisiting the genome of the Pacific oyster, $C$. gigas, and screening our new unpublished oyster transcript sequences, we identified at least 21 genes coding for transcripts of the Toll pathway. Table 2 reports them in comparison to the M. galloprovincialis data.

\subsection{Constitutive transcription levels of the Toll pathway genes in M. galloprovincialis}

Constitutive transcription in hemocytes and five dissected tissues has been visualized by running in gel electrophoresis specific amplicons obtained after 35 cycles of PCR (Fig. 2). Based on visual aspect of the bands, the housekeeping gene MgEF1- $\alpha$ was similarly expressed in all tissues. The majority of the analyzed Toll pathway genes were expressed ubiquitously, although their transcription levels appeared very different from one tissue to another: $M g I R A K-a$ and $M g E C S I T$, for instance. Few genes were almost undetectable in more than one tissue after 35 cycles of PCR: the MgRIPlike, MgIKK-1 and MgIKK-2 transcripts, for instance. All analyzed mRNAs were present in gills, many of them in substantial amounts.

\subsection{Toll pathway gene transcription levels induced by bacterial/fungal antigens in M. galloprovincialis hemocytes}

Transcription levels of the Toll pathway genes as detected in variously challenged mussels, presented as red (induction) or green (inhibition) squares according to the time p.i. (3-24 h) are summarized in Table 4. Immune stimulation was considered productive when the gene expression level was statistically significantly different from both unchallenged and SSW injected mussels. After bacterial challenge, the transcription of almost all the analyzed genes was modified, except MgTLR-a/-n/-r, MgTOLLIP and MgTAK-1. Injection with Gram-negative vibrios up-regulated various genes and down-regulated MgECSIT and MgTRAF-3, meanwhile the expression of MgRIP-like and MgTAK-1 was not affected. No marked difference has been noticed in the response induced by the two Vibrios, excepted regarding MgMyD88-b which transcription was induced after injection with $V$. anguillarum, but not with $V$. splendidus. Compared to the injection with the whole bacterial

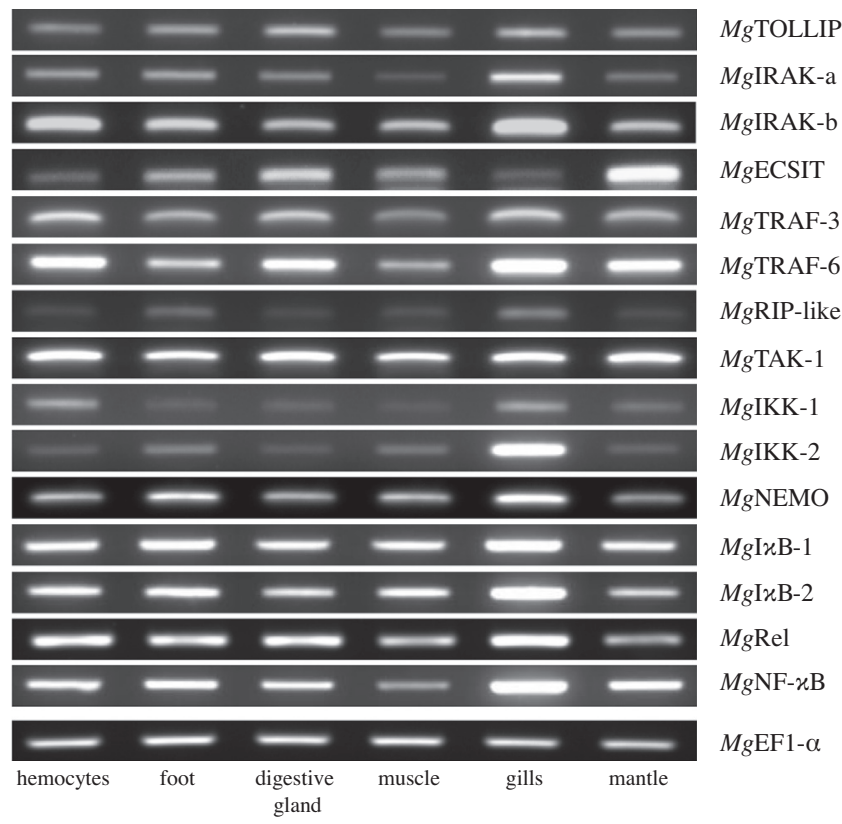

Fig. 2. Constitutive transcription levels of Toll pathway and of MgEF1- $\alpha$ genes in different tissues of $M$. galloprovincialis as observed in gel electrophoresis after 35 cycles of end-point PCR.

cells, the injection with LPS did not affect the transcription, excepted a light induction of MgMyD88-a at 6 and $9 \mathrm{~h}$ p.i. The challenge with the Gram-positive M. luteus did not result in marked differences compared to the effects of Gram-negative bacteria, excepted that transcription levels peaked at $6 \mathrm{~h}$ p.i. rather than at $3 \mathrm{~h}$ p.i. The only exceptions were the moderate up-regulation of MgTLR-b and MgRIP-like, only at 24 h p.i., not observed after injection with Vibrios. By contrast, immune stimulation with PGN was ineffective. The injection with $F$. oxysporum did not change the transcription levels of many Toll pathway genes, though some genes appeared up-regulated (MgTLR-i, MgMyD88-c, MgIRAK-a, and $M g I K K-2)$, and other genes down-regulated (MgECSIT and MgRIP-like). In detail, the gene elements from the last part of the signaling cascade were not affected, Same erratic gene transcription trends were also detected following injection with BG, but with less intensity.

Time-related effect of challenge with bacterial cells, fungus spores and microbial antigens on the transcription of 3 genes, selected for their clear inducibility and not previously published, such as the various MgTLR and MgMyD88 transcripts (Toubiana et al., 2013) are detailed in Fig. 3. Injection with Gram-negative and Gram-positive bacteria resulted in significant up-regulation as soon as $3 \mathrm{~h}$ p.i., effect still evident after $24 \mathrm{~h}$ in the case of MgIKK-2 and MgIKB-1. In contrast, injection with LPS or PGN preparations was ineffective. The response to the injection with $F$. oxysporum never started before $9 \mathrm{~h}$ p.i. and was ineffective on $\mathrm{MgI \kappa \textrm {B } - 1}$ transcription. Injection with BG induced the transcription of the sole MgIRAK-a, and only at $3 \mathrm{~h}$ p.i. Finally, and despite the fact injection with SSW also significantly induced the expression of

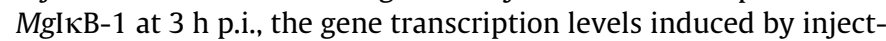
ing whole bacteria and fungus were always significantly higher.

\subsection{PAMP-induced activation of Toll signaling pathway in hemocytes from other bivalves}

Gene transcription of intermediate molecules has been analyzed in several bivalves in response to various stimulations. None of these reports addressed the complete Toll pathway in the same 
Table 4

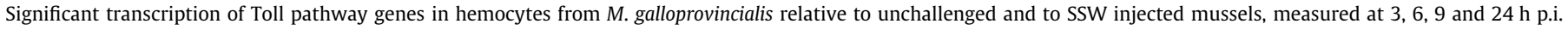

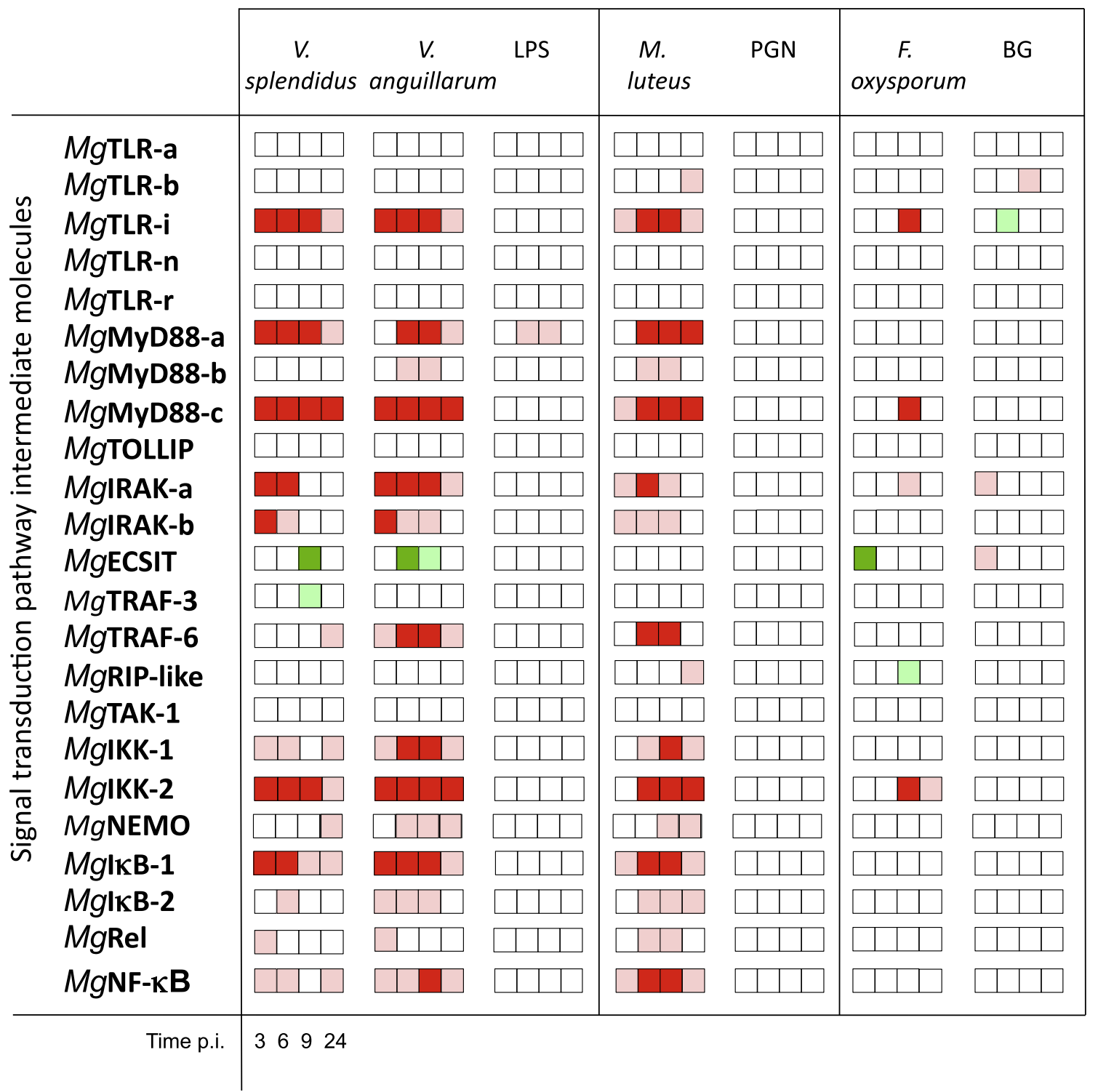

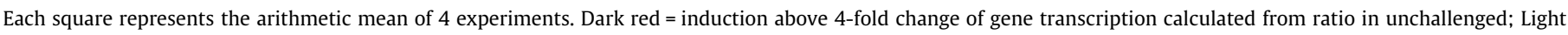

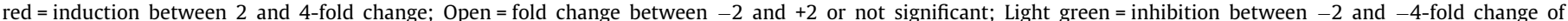

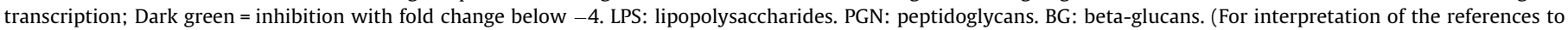
colour in this figure legend, the reader is referred to the web version of this article.)

animal. Moreover, nature of stimulant, duration of challenge, route of challenge (immersion, in vivo injection or in vitro incubation), and targeted tissues, were so diverse that comprehensive scheme and comparison between species cannot be outlined. Transcription levels measured in bivalve hemocytes following the single in vivo injection with different bacteria and PAMPs, and resulting from bibliographic analysis, are summarized in Table 5. Few studies are available, with the majority of the challenges involving Gram-negative bacteria or LPS, a fact which might sound surprising as the Toll pathway is reported to be triggered by Gram-positive bacteria in invertebrates (Ferrandon et al., 2007, 2004). But infections in marine animals have been mainly associated with Gramnegative bacteria, mostly Vibrios, a reason to analyze defense mechanisms towards such bacteria. Injection with Gram-negative Vibrios or LPS resulted in up-regulation of several transcripts, including the last elements, I $\kappa \mathrm{B}$, Rel and NF- $\kappa \mathrm{B}$. Gram-positive bacteria or PGN have been tested only on C. gigas (no effect on Rel transcription) and $C$. farreri (induction of Rel). Following these analysis, we cannot conclude on specific Rel activation.

\section{Discussion}

We isolated the first transcripts related to the Toll signaling pathway in bivalves in 1998: IKK from C. gigas (AF051320) (Escoubas et al., 1999). Later, partial MgRel (deposited in 2001, AY039648) has been identified as constitutively expressed at significantly lower levels in hemocytes (Montagnani et al., 2004). Then, ECSIT (BQ427193) and TRAF-3 (BQ426746), deposited in 2002, were also reported as constitutively expressed during onto- 


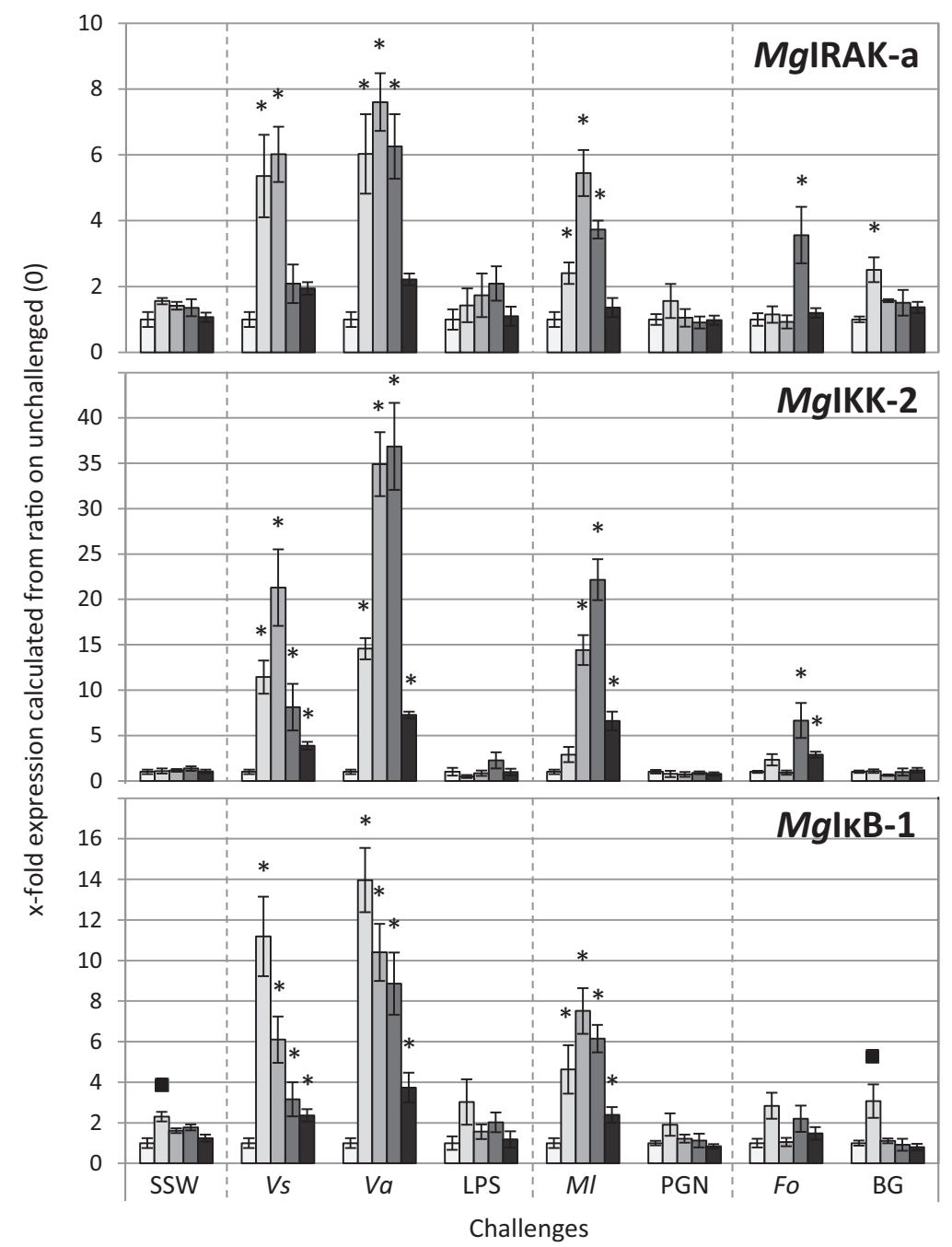

$0 \square$ 3h $\square$ 6h $\square$ 9h $\square$ 24h post-injections

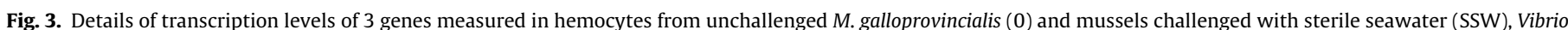

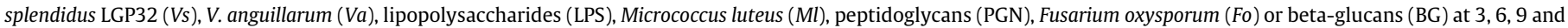

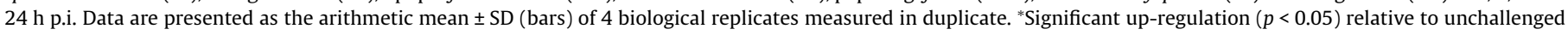
and to SSW injected mussels collected at the same time p.i. $\mathbf{\square}$ : Significant down-regulation $(p<0.05)$ relative to unchallenged mussels.

genesis (Tirape et al., 2007). Although only some transcripts have been evidenced, several hypothetical schemes have been constructed in bivalves by analogy with Drosophila and mammals, i.e. in the Pacific oyster, C. gigas (Montagnani et al., 2004), the mussels, M. galloprovincialis (Venier et al., 2011) and M. edulis (Philipp et al., 2012), and the Manila clam, Ruditapes philippinarum (Moreira et al., 2012). The 454 reads from M. edulis (Philipp et al., 2012) together with new Illumina assembly reads that we have obtained from M. galloprovincialis and C. gigas allowed us a more complete investigation of the bivalve transcriptomes. Accordingly, the present study adds 14 complete and one incomplete cds of intermediate transcript elements of the Toll signaling pathway from $M$. galloprovincialis, plus 11 from $M$. edulis and 21 from $C$. gigas.

The restricted number of intermediate transcript elements identified in Mytilus compared to C. gigas suggest that the present sequence data are not exhaustive and only the bivalve genome analysis will give the complete information. Interesting was the diversity of $C$. gigas TRAF and IKK. One can hypothesize that such diversity also exists in Mytilus. The question is how much redundance are the transcripts of the signaling pathway, i.e. what is the number of isoforms really used versus the resolution level due to advanced sequencing techniques? Instructive was the phylogenetic analysis of each of the transcripts. Some of bivalve transcripts clearly segregated together, closer to deuterostomes than to arthropods: TOLLIP, TAK-1 and NEMO. Others were close to known sub-groups: IRAK-a and -b respectively close to 1 and 4; TRAF-3 close to human $3 / 5$ and -6 close to human 6 and Drosophila 2; IKK-1 close to $\alpha / \beta$ and -2 close to epsilon/TBK1. The phylogenetic analysis allowed to discriminate between Rel, clearly belonging to human Rel-B/c-rel/p65, and NF- $\kappa B$ belonging to human p100/ 105. I $\mathrm{B}$ appeared as an exception with a bivalve homogeneous cluster clearly separated from deuterostomes and arthropods. Finally, ECSIT exemplifies a gene transcript perfectly conserved through evolution, as expected.

All the analyzed genes were constitutively expressed in gills. Such general high level of transcription might be related to the functional role of the gills located at the interface between external and internal environment and largely infiltrated by hemocytes. Some of the genes expressed in gills were not expressed in hemocytes, so revealing the transcriptional specificity of both tissues. In 
Table 5

Gene regulation of Toll pathway transcript elements in hemocytes of seven bivalves following in vivo injections, as found in bibliography.

\begin{tabular}{|c|c|c|c|c|c|c|c|}
\hline \multirow{2}{*}{$\begin{array}{c}\text { Toll/NF-kB } \\
\text { intermediate } \\
\text { molecules }\end{array}$} & \multicolumn{4}{|c|}{ Challenges } & \multirow[b]{2}{*}{ Species } & \multirow{2}{*}{$\begin{array}{c}\text { Accession } \\
\text { numbers }\end{array}$} & \multirow[b]{2}{*}{ References } \\
\hline & $\begin{array}{l}\text { Gram- } \\
\text { negative } \\
\text { bacteria }\end{array}$ & LPS & $\begin{array}{l}\text { Gram- } \\
\text { positive } \\
\text { bacteria }\end{array}$ & PGN & & & \\
\hline \multirow{2}{*}{ TLR } & & + & & & Chlamys farreri & DQ350772 & (Wang et al., 2011) \\
\hline & - & & & & Mya arenaria & UN & (Mateo et al., 2010) \\
\hline MyD88 & & + & & & Chlamys farreri & DQ249918 & (Wang et al., 2011) \\
\hline IRAK-4 & + & & & & Mya arenaria & UN & (Mateo et al., 2010) \\
\hline ECSIT & + & & & & Crassostrea gigas & HQ225834 & (Zhang et al., 2012b) \\
\hline TRAF-6 & & + & & & Chlamys farreri & DQ350773 & (Wang et al., 2011) \\
\hline TRAF-7 & - & & & & C. hongkongensis & JN029961 & (Fu et al., 2011) \\
\hline \multirow{6}{*}{$\mathrm{I} \kappa \mathrm{B}$} & + & & & & Crassostrea gigas & DQ250326 & (Zhang et al., 2011) \\
\hline & + & + & & & Pinctada fucata & EU871726 & (Zhang et al., 2009) \\
\hline & + & & & & Saccostrea glomerata & GH612349 & $\begin{array}{c}\text { (Green and Barnes, } \\
\text { 2009) }\end{array}$ \\
\hline & & + & & & Chlamys farreri & DQ852572 & (Wang et al., 2011) \\
\hline & + & & & & $\begin{array}{l}\text { Argopectens } \\
\text { irradians }\end{array}$ & FJ824733 & (Mu et al., 2010) \\
\hline & + & + & & & $\begin{array}{c}\text { Ruditapes } \\
\text { phillipinarum }\end{array}$ & JF683414 & $\begin{array}{c}\text { (Lee et al., 2013; } \\
\text { Moreira et al., 2012a; } \\
\text { Moreira et al., 2012b) }\end{array}$ \\
\hline $\begin{array}{l}\text { Rel-1 } \\
\text { Rel-2 }\end{array}$ & o & & $\mathrm{o}$ & & Crassostrea gigas & $\begin{array}{l}\text { AY039648 } \\
\text { AY039649 }\end{array}$ & $\begin{array}{c}\text { (Montagnani et al., } \\
\text { 2004) }\end{array}$ \\
\hline Rel & & + & & + & Chlamys farreri & JX841198 & (Zhou et al., 2013) \\
\hline$N F-\kappa B$ & & + & & & Chlamys farreri & UN & (Wang et al., 2011) \\
\hline
\end{tabular}

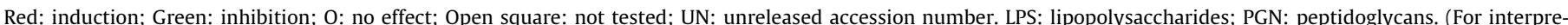
tation of the references to colour in this figure legend, the reader is referred to the web version of this article.) 
contrast but not surprising, the genes expressed in hemocytes were also detected in all the analyzed tissues as expected for circulating hemocytes.

Experimental injection of M. galloprovincialis with Gram-negative bacteria induced intense gene expression as soon as $3 \mathrm{~h}$ p.i., whereas the gene-up-regulation induced by Gram-positive bacteria peaked not before $6 \mathrm{~h}$ p.i. The MgECSIT transcription was inhibited by Gram-negative bacteria and fungus, or unaffected by LPS, PGN and Gram-positive bacteria, or slightly induced by BG. According to its name, "evolutionarily conserved signaling intermediate in Toll pathways", and its location within the pathway between the two induced IRAK and TRAF, we were expecting that such transcript could also be over-expressed. Possibly, either the challenges performed in $M$. galloprovincialis did not provide an optimal immune stimulation, or such stimulation may have occurred too rapidly, being nearly over at $3 \mathrm{~h}$ p.i.

In response to the $F$. oxysporum injection, we could trace the transcription of 6 genes, with no evident transcriptional change in the down-stream elements $I \kappa B$, Rel and NF- $\kappa B$. We previously reported that MgTLR-i, MgMyD88-c and antifungal mytimycin gene transcriptions were induced at $9 \mathrm{~h}$ p.i. with $F$. oxysporum (Sonthi et al., 2012; Toubiana et al., 2013). As only few genes of the Toll pathway were up-regulated, we hypothesized that the response to fungus could start with TLR/MyD88 activation and might then involve another unelucidated signaling cascade. In humans, the binding of pathogenic components to TLRs initiates several intricate signaling pathways: the MyD88-dependent one with quick activation of NF- $\kappa B$, the MyD88-independent pathway with the induction of IFN- $\beta$ (interferon) through TRIF (TIR-domain-containing adapterinducing interferon- $\beta$ ), the TNF (tumor necrosis factor) pathway involving protein kinases, the JAK/STAT (Janus kinase/signal transducer and activator of transcription) pathway, and the MAPK (mitogen-activated protein kinase) pathway (Broz and Monack,
2013; Stuart et al., 2013). Some of these cascades are not considered herein and might also exist in bivalves.

The question remains regarding bivalve RIP. Its structural domain organization is similar to the one of arthropod IMD, but BLAST analysis allocated it to its deuterostome counterpart, RIP. In addition, experimental challenges with Gram-negative bacteria or LPS did not trigger the expression of such gene, as expected if involved in the IMD pathway (Engstrom, 1999). As a consequence, we have no proof on the existence of a specific IMD-like pathway in bivalves. Both bacteria strains appeared to stimulate the same Toll signaling pathway.

In the present study, we observed that PGN (related to Grampositive bacteria cell wall) had no effect, whereas LPS (related to Gram-negative bacteria cell wall) and BG (related to fungal cell wall) had marginal effect on the transcription levels of one or four genes of the Toll pathway suggesting that a purified preparation of such determinants cannot activate the TLRs as whole microbial cells do. Alternatively, suboptimal dosing of the immune stimulants based on the literature related to other bivalves, cannot be excluded.

Based on the gene which whose expression appeared modified after challenge, we propose a comprehensive reading frame of the Toll signaling pathways in M. galloprovincialis (Fig. 4). The mussel genes expressed in response to bacteria likely constitute a complete pathway from TLR to NF- $\kappa B$, similar to Toll/TLR pathways traced in model species; however, the involvement and the role of intermediate transcript elements is still hypothetical as based on functional analogy (Valanne et al., 2011). The expression of MgIKK-1 (IKK- $\alpha / \beta$ sub-group) and MgNEMO (IKK- $\gamma$ ) genes are both induced by injection of bacteria, however with less intensity for MgNEMO. These first results confirmed the hypothesis on the existence of an IKK complex in molluscs, as in insects and vertebrates. Interestingly, the maximum stimulation of NF- $\kappa \mathrm{B}$ occurring

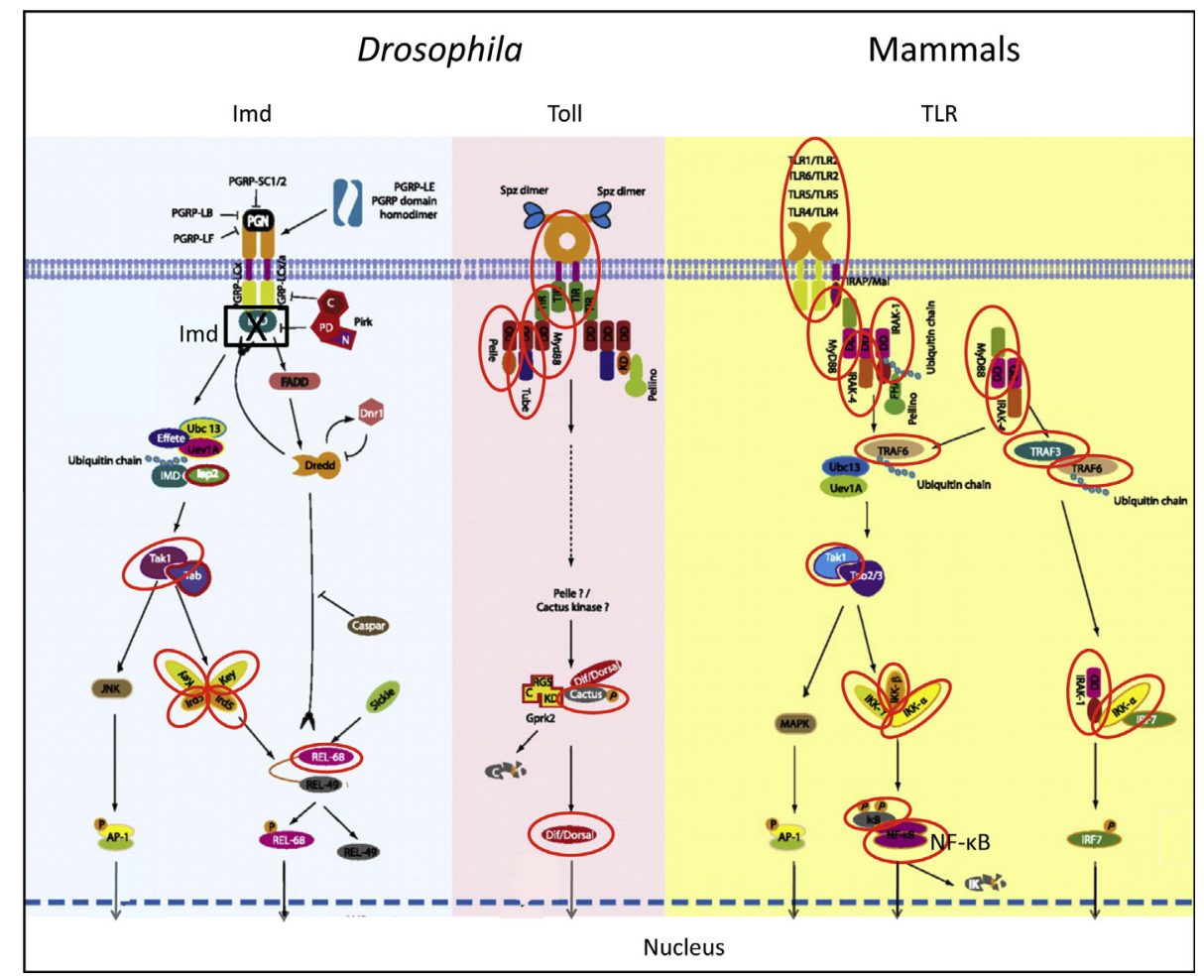

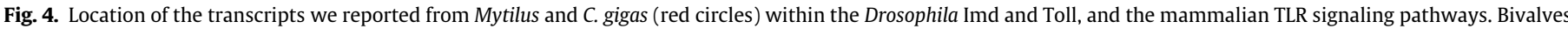

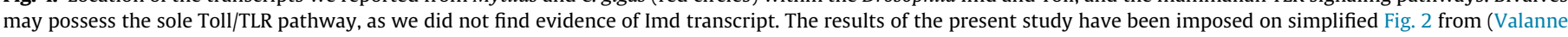

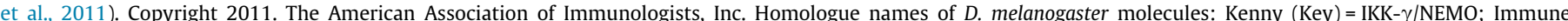

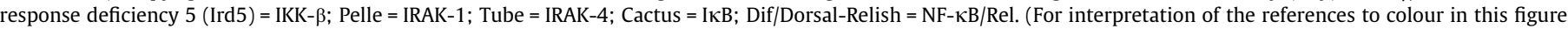
legend, the reader is referred to the web version of this article.) 
later than its inhibitor $\mathrm{I} \kappa \mathrm{B}$, suggested a negative regulatory feedback of the NF- $\kappa \mathrm{B}$ as demonstrated for Cactus, the Drosophila's homologue of I $\kappa B$ (Nicolas et al., 1998). Similarly, the temporal control of NF- $\kappa B$ activation in mammals is coordinated by degradation and synthesis of $I \kappa B$ proteins which are responsible for the strong negative regulation allowing a fast turn-off of the NF- $\kappa B$ response (Hoffmann et al., 2002). On the opposite, up- and down-regulation of the various AMP genes in M. galloprovincialis was reported by several laboratories using different techniques (Costa et al., 2009b; Li et al., 2010; Mitta et al., 2000a; Pallavicini et al., 2008; Venier et al., 2011) and appears somehow conflicting. Details related to the experimental challenges (e.g. live versus heat-inactivated microbes, shell notching versus shell slitting), differences in sampling time and also extended individual variability of AMP gene transcription levels (Cantet et al., 2012, 2009a; Romero et al., 2011) generated contrasted results and do not allow to draw a common scheme. Finally, gene transcription depends on half-time and degradation rate of proteins after challenge, as demonstrated in Drosophila (Nicolas et al., 1998).

In conclusion, we reported and revised here the existence of genes/transcripts mediating the Toll signaling pathway in three bivalves. The expression of most Toll signaling genes was induced after bacterial injection in M. galloprovincialis, whatever the Gram staining. By contrast, a fungus and purified PAMPs did not substantially activate the Toll pathway. Next step will be to link the activation of the Toll pathway to the transcription of AMP genes, and to locate NF- $\kappa B$ regulatory binding site(s) within the promoter regions of bivalve AMP genes. Alternatively, quantification of the related proteins and/or the modulator role of post-translational modifications (e.g. phosphorylation and ubiquitination) could add new facts on the functionality of the Toll pathway in molluscs.

\section{Acknowledgements}

This work was funded in part by the EU program BIVALIFE (KBBE-2010-266157). Authors are grateful to Philippe Clair for advices and management of the qPCR Platform, to Romain Gros for technical assistance, and to Prof. Edwin L. Cooper from University of California-Los Angeles for critical reading and language improvement. S.G. and M.C. have been supported in part by FFR Grant.

\section{Appendix A. Supplementary data}

Supplementary data associated with this article can be found, in the online version, at http://dx.doi.org/10.1016/j.dci.2014.03.021.

\section{References}

Bettencourt, R., Roch, P., Stefanni, S., Rosa, D., Colaco, A., Santos, R.S., 2007. Deep sea immunity: unveiling immune constituents from the hydrothermal vent musse Bathymodiolus azoricus. Mar. Environ. Res. 64, 108-127.

Broz, P., Monack, D.M., 2013. Newly described pattern recognition receptors team up against intracellular pathogens. Nat. Rev. Immunol. 13, 551-565.

Cantet, F., Toubiana, M., Parisi, M.G., Sonthi, M., Cammarata, M., Roch, P., 2012. Individual variability of mytimycin gene expression in mussel. Fish Shellfish Immunol. 33, 641-644.

Capelluto, D.G., 2012. Tollip: a multitasking protein in innate immunity and protein trafficking. Microbes Infect. 14, 140-147.

Costa, M.M., Dios, S., Alonso-Gutierrez, J., Romero, A., Novoa, B., Figueras, A., 2009a. Evidence of high individual diversity on myticin C in mussel (Mytilus galloprovincialis). Dev. Comp. Immunol. 33, 162-170.

Costa, M.M., Prado-Alvarez, M., Gestal, C., Li, H., Roch, P., Novoa, B., Figueras, A. 2009b. Functional and molecular immune response of Mediterranean mussel (Mytilus galloprovincialis) haemocytes against pathogen-associated molecular patterns and bacteria. Fish Shellfish Immunol. 26, 515-523.

Cunningham, C., Hikima, J., Jenny, M.J., Chapman, R.W., Fang, G.C., Saski, C., Lundqvist, M.L., Wing, R.A., Cupit, P.M., Gross, P.S., Warr, G.W., Tomkins, J.P., 2006. New resources for marine genomics: bacterial artificial chromosome libraries for the Eastern and Pacific oysters (Crassostrea virginica and C. gigas). Mar. Biotechnol. (NY) 8, 521-533.
Eddy, S.R., 2011. Accelerated profile HMM searches. PLoS Comput. Biol. 7, e1002195.

Engstrom, Y., 1999. Induction and regulation of antimicrobial peptides in Drosophila. Dev. Comp. Immunol. 23, 345-358.

Escoubas, J.M., Briant, L., Montagnani, C., Hez, S., Devaux, C., Roch, P., 1999. Oyster IKK-like protein shares structural and functional properties with its mammalian homologues. FEBS Lett. 453, 293-298.

Ferrandon, D., Imler, J.L., Hoffmann, J.A., 2004. Sensing infection in Drosophila: toll and beyond. Semin. Immunol. 16, 43-53.

Ferrandon, D., Imler, J.L., Hetru, C., Hoffmann, J.A., 2007. The Drosophila systemic immune response: sensing and signalling during bacterial and fungal infections. Nat. Rev. Immunol. 7, 862-874.

Gay, M., Berthe, F.C., Le Roux, F., 2004. Screening of Vibrio isolates to develop an experimental infection model in the Pacific oyster Crassostrea gigas. Dis. Aquat. Organ. 59, 49-56.

Gestal, C., Costa, M., Figueras, A., Novoa, B., 2007. Analysis of differentially expressed genes in response to bacterial stimulation in hemocytes of the carpet-shell clam Ruditapes decussatus: identification of new antimicrobial peptides. Gene 406, $134-143$.

Gonzalez, M., Gueguen, Y., Desserre, G., de Lorgeril, J., Romestand, B., Bachere, E., 2007. Molecular characterization of two isoforms of defensin from hemocytes of the oyster Crassostrea gigas. Dev. Comp. Immunol. 31, 332-339.

Gueguen, Y., Cadoret, J.P., Flament, D., Barreau-Roumiguiere, C., Girardot, A.L., Garnier, J., Hoareau, A., Bachere, E., Escoubas, J.M., 2003. Immune gene discovery by expressed sequence tags generated from hemocytes of the bacteria-challenged oyster, Crassostrea gigas. Gene 303, 139-145.

Gueguen, Y., Herpin, A., Aumelas, A., Garnier, J., Fievet, J., Escoubas, J.M., Bulet, P., Gonzalez, M., Lelong, C., Favrel, P., Bachere, E., 2006. Characterization of a defensin from the oyster Crassostrea gigas. Recombinant production, folding, solution structure, antimicrobial activities, and gene expression. J. Biol. Chem. 281, 313-323.

Hoffmann, J.A., 2003. The immune response of Drosophila. Nature 426, 33-38.

Hoffmann, A., Levchenko, A., Scott, M.L., Baltimore, D., 2002. The IkappaB-NFkappaB signaling module: temporal control and selective gene activation. Science 298, 1241-1245.

Kim, S.Y., Baik, K.H., Baek, K.H., Chah, K.H., Kim, K.A., Moon, G., Jung, E., Kim, S.T., Shim, J.H., Greenblatt, M.B., Chun, E., Lee, K.Y., 2014. S6K1 negatively regulates TAK1 Activity in the Toll-like receptor signaling pathway. Mol. Cell. Biol. 34, 510-521.

Lemaitre, B., Hoffmann, J., 2007. The host defense of Drosophila melanogaster. Annu. Rev. Immunol. 25, 697-743.

Li, H., Venier, P., Prado-Alvarez, M., Gestal, C., Toubiana, M., Quartesan, R., Borghesan, F., Novoa, B., Figueras, A., Roch, P., 2010. Expression of Mytilus immune genes in response to experimental challenges varied according to the site of collection. Fish Shellfish Immunol. 28, 640-648.

Li, H., Parisi, M.-G., Parrinello, N., Cammarata, M., Roch, P., 2011. Molluscan antimicrobial peptides, a review from activity-based evidences to computerassisted sequences. Invertebr. Survey J. 8, 85-97.

Mitta, G., Hubert, F., Noel, T., Roch, P., 1999a. Myticin, a novel cysteine-rich antimicrobial peptide isolated from haemocytes and plasma of the mussel Mytilus galloprovincialis. Eur. J. Biochem. 265, 71-78.

Mitta, G., Vandenbulcke, F., Hubert, F., Roch, P., 1999b. Mussel defensins are synthesised and processed in granulocytes then released into the plasma after bacterial challenge. J. Cell Sci. 112, 4233-4242.

Mitta, G., Hubert, F., Dyrynda, E.A., Boudry, P., Roch, P., 2000a. Mytilin B and MGD2, two antimicrobial peptides of marine mussels: gene structure and expression analysis. Dev. Comp. Immunol. 24, 381-393.

Mitta, G., Vandenbulcke, F., Hubert, F., Salzet, M., Roch, P., 2000b. Involvement of mytilins in mussel antimicrobial defense. J. Biol. Chem. 275, 12954-12962.

Montagnani, C., Kappler, C., Reichhart, J.M., Escoubas, J.M., 2004. Cg-Rel, the first Rel/NF-kappaB homolog characterized in a mollusk, the Pacific oyster Crassostrea gigas. FEBS Lett. 561, 75-82.

Montagnani, C., Labreuche, Y., Escoubas, J.M., 2008. Cg-IkappaB, a new member of the IkappaB protein family characterized in the pacific oyster Crassostrea gigas. Dev. Comp. Immunol. 32, 182-190.

Moreira, R., Balseiro, P., Planas, J.V., Fuste, B., Beltran, S., Novoa, B., Figueras, A. 2012 Transcriptomics of in vitro immune-stimulated hemocytes from the Manila clam Ruditapes philippinarum using high-throughput sequencing. PLoS ONE 7, e35009.

Munitic, I., Giardino Torchia, M.L., Meena, N.P., Zhu, G., Li, C.C., Ashwell, J.D., 2013. Optineurin insufficiency impairs IRF3 but not NF-kappaB activation in immune cells. J. Immunol. 191, 6231-6240.

Nicolas, E., Reichhart, J.M., Hoffmann, J.A., Lemaitre, B., 1998. In vivo regulation of the IkappaB homologue cactus during the immune response of Drosophila. J. Biol. Chem. 273, 10463-10469.

Pallavicini, A. Costa, M.M., Gestal, C., Dreos, R., Figueras, A., Venier, P., Novoa, B. 2008. High sequence variability of myticin transcripts in hemocytes of immunestimulated mussels suggests ancient host-pathogen interactions. Dev. Comp. Immunol. 32, 213-226.

Perrigault, M., Tanguy, A., Allam, B., 2009. Identification and expression of differentially expressed genes in the hard clam, Mercenaria mercenaria, in response to quahog parasite unknown (QPX). BMC Genomics 10, 377.

Philipp, E.E., Kraemer, L., Melzner, F., Poustka, A.J., Thieme, S., Findeisen, U. Schreiber, S., Rosenstiel, P., 2012. Massively parallel RNA sequencing identifies a complex immune gene repertoire in the lophotrochozoan Mytilus edulis. PLoS ONE 7, e33091. 
Ren, Q., Li, M., Zhang, C.Y., Chen, K.P., 2011. Six defensins from the triangle-shell pearl mussel Hyriopsis cumingii. Fish Shellfish Immunol. 31, 1232-1238.

Romero, A., Dios, S., Poisa-Beiro, L., Costa, M.M., Posada, D., Figueras, A., Novoa, B., 2011. Individual sequence variability and functional activities of fibrinogenrelated proteins (FREPs) in the Mediterranean mussel (Mytilus galloprovincialis) suggest ancient and complex immune recognition models in invertebrates. Dev. Comp. Immunol. 35, 334-344.

Schmitt, P., de Lorgeril, J., Gueguen, Y., Destoumieux-Garzon, D., Bachere, E., 2012 Expression, tissue localization and synergy of antimicrobial peptides and proteins in the immune response of the oyster Crassostrea gigas. Dev. Comp. Immunol. 37, 363-370.

Shifera, A.S., 2010. The zinc finger domain of IKKgamma (NEMO) protein in health and disease. J. Cell Mol. Med. 14, 2404-2414.

Sonthi, M., Cantet, F., Toubiana, M., Trapani, M.R., Parisi, M.G., Cammarata, M., Roch, P., 2012. Gene expression specificity of the mussel antifungal mytimycin (MytM). Fish Shellfish Immunol. 32, 45-50.

Stuart, L.M., Paquette, N., Boyer, L., 2013. Effector-triggered versus pattern-triggered immunity: how animals sense pathogens. Nat. Rev. Immunol. 13, 199-206.

Talavera, G., Castresana, J., 2007. Improvement of phylogenies after removing divergent and ambiguously aligned blocks from protein sequence alignments. Syst. Biol. 56, 564-577.

Tanguy, M., McKenna, P., Gauthier-Clerc, S., Pellerin, J., Danger, J.M., Siah, A., 2013. Functional and molecular responses in Mytilus edulis hemocytes exposed to bacteria, Vibrio splendidus. Dev. Comp. Immunol. 39, 419-429.

Tirape, A., Bacque, C., Brizard, R., Vandenbulcke, F., Boulo, V., 2007. Expression of immune-related genes in the oyster Crassostrea gigas during ontogenesis. Dev. Comp. Immunol. 31, 859-873.
Toubiana, M., Gerdol, M., Rosani, U., Pallavicini, A., Venier, P., Roch, P., 2013. Toll-like receptors and MyD88 adaptors in Mytilus: Complete cds and gene expression levels. Dev. Comp. Immunol. 40, 158-166.

Valanne, S., Wang, J.H., Ramet, M., 2011. The Drosophila Toll signaling pathway. J. Immunol. 186, 649-656.

Venier, P., Varotto, L., Rosani, U., Millino, C., Celegato, B., Bernante, F., Lanfranchi, G., Novoa, B., Roch, P., Figueras, A., Pallavicini, A., 2011. Insights into the innate immunity of the Mediterranean mussel Mytilus galloprovincialis. BMC Genomics $12,69$.

Wu, X., Xiong, X., Xie, L., Zhang, R., 2007. Pf-Rel, a Rel/nuclear factor-kappaB homolog identified from the pearl oyster, Pinctada fucata. Acta Biochim. Biophys. Sin. (Shanghai) 39, 533-539.

Xiong, X., Feng, Q., Chen, L., Xie, L., Zhang, R., 2008. Cloning and characterization of an IKK homologue from pearl oyster, Pinctada fucata. Dev. Comp. Immunol. 32 $15-25$.

Zhang, D., Lin, J., Han, J., 2010. Receptor-interacting protein (RIP) kinase family. Cell. Mol. Immunol. 7, 243-249.

Zhang, G., Fang, X., Guo, X., Li, L., Luo, R., Xu, F., Yang, P., Zhang, L., Wang, X., Qi, H., Xiong, Z., Que, H., Xie, Y., Holland, P.W., Paps, J., Zhu, Y., Wu, F., Chen, Y., Wang, J., Peng, C., Meng, J., Yang, L., Liu, J., Wen, B., Zhang, N., Huang, Z., Zhu, Q., Feng, Y., Mount, A., Hedgecock, D., Xu, Z., Liu, Y., Domazet-Loso, T., Du, Y., Sun, X., Zhang, S., Liu, B., Cheng, P., Jiang, X., Li, J., Fan, D., Wang, W., Fu, W., Wang, T., Wang, B. Zhang, J., Peng, Z., Li, Y., Li, N., Chen, M., He, Y., Tan, F., Song, X., Zheng, Q., Huang, R., Yang, H., Du, X., Chen, L., Yang, M., Gaffney, P.M., Wang, S., Luo, L., She, Z. Ming, Y., Huang, W., Huang, B., Zhang, Y., Qu, T., Ni, P., Miao, G., Wang, Q. Steinberg, C.E., Wang, H., Qian, L., Liu, X., Yin, Y., 2012. The oyster genome reveals stress adaptation and complexity of shell formation. Nature 490, 49-54. 